\title{
Analisis Pengaruh Social Distancing, Work from Home dan Aplikasi Video Call terhadap Produktivitas Organisasi: Studi Kasus pada Permukiman di DKI Jakarta (The Effect of Social Distancing, Work from Home and Video Call Applications on Organizational Productivity: A Case Study of Settlements in DKI Jakarta)
}

Dewi Puspaningtyas Faeni ${ }^{1,}$ Ratih Puspitaningtyas Faeni ${ }^{2}$, Ravindra Safitra Hidayat ${ }^{3}$, Retno Fuji Oktaviani ${ }^{4}$, Rinny Meidiyustiani ${ }^{5}$

Dosen Fakultas Ekonomi dan Bisnis, Universitas Budi Luhur, Jakarta Selatan 1,2,3,4,5

dewifaeni@budiluhur.ac.id ${ }^{1}$, ratih.puspitaningtyas@budiluhur.ac.id ${ }^{2}$,

ravindra.safitra@budiluhur.ac.id ${ }^{3}$, retno.fujioktaviani@budiluhur.ac.id ${ }^{4}$,

rinny.meidiyustiani@budiluhur.ac.id ${ }^{5}$

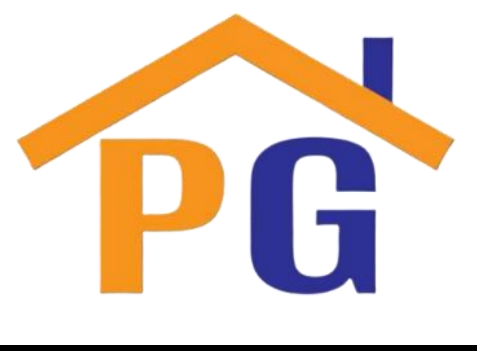

Riwayat Artikel

Diterima pada 1 Maret 2021

Direvisi pada 24 Mei 2021

Disetujui pada 24 Mei 2021

\begin{abstract}
Purpose: This research aimed to analyze the influence of Social Distancing, Work from Home and Video Call applications towards Organizational Productivity.

Method: This type of research is a quantitative descriptive research. The analysis tool used in this study is SmartPLS 3.0. The population of this study is 9880 people. The samples studied were 130 people using the Simple Random Sampling method. The sampling technique refers to the Slovin formula. The results stated that the analysis of Social Distancing influence, Work From Home and Video Call application $(0,052),(0,047)$ and $(0,924)$.

Results: Based on test of R Square, Productivity of the Organization as Endogenous variable affects $98.6 \%$ while the remaining $1.4 \%$ is influenced by other factors.

Keywords: Organizational Productivity, Social Distancing, Work from Home, Video Call Applications

How to Cite: Faeni, D. P., Faeni, R. P., Hidayat, R. S., Oktaviani, R. F., \& Meidiyustiani, R. (2021) Analisis Pengaruh Social Distancing, Work from Home dan Aplikasi Video Call terhadap Produktivitas Organisasi: Studi Kasus pada Permukiman di DKI Jakarta. Studi Ilmu Manajemen dan Organisasi, 2(1), 11-18.
\end{abstract}

\section{Pendahuluan}

Dunia dilanda kondisi pandemik Covid-19 yang berpengaruh pada kondisi di Indonesia. Penyebaran virus Covid-19 di Indonesia telah mencapai 1.329.074 kasus positif dengan rincian 35.981 orang meninggal dunia dan 1.136.054 orang sembuh (BPS, 2021). Di Indonesia diberlakukan kebijakan PSBB (Pembatasan Sosial Berskala Besar) sebagai respon pencegahan penyebaran virus Covid-19. Kasus Covid-19 terbanyak berada di DKI Jakarta. Penyebaran Covid-19 di Jakarta mencapai 6.208 orang positif. Jakarta sebagai Ibukota negara tidak memberlakukan kebijakan lock down secara total, lebih memberlakukan PSBB sebagai sebuah kebijakan dan anjuran menjaga jarak atau trend sebagai istilah Social Distancing. Himbauan menjaga jarak atau Social Distancing diharapkan dapat menekan laju penyebaran pandemi virus Covid-19, karena diyakini tindakan menjaga jarak sosial dengan cara mengimplementasikan Konsep 5 M (Memakai masker, Mencuci tangan, Menjaga Jarak, Mengurangi mobilitas dan Memghindari kerumunan) diyakini dapat menahan laju penyebaran virus. Pengimplementasian Konsep $5 \mathrm{M}$ ini diharapkan mampu menahan laju proleferasi virus Covid- 19 dapat ditekan. Kebijakan $5 \mathrm{M}$ yang intinya menjaga jarak atau social distancing berpengaruh kepada kebijakan derivatif dengan diberlakukannya sistem Work From Home (WFH) atau bekerja dari rumah. WFH sebagai sebuah solusi yang efektif, karena mayoritas perkantoran di Jakarta menggunakan 
sistem pendingin ruangan yang juga diyakini sebagai pengantar meningkatnya jumlah pasien Covid19 pada klaster perkantoran, maka WFH merupakan aktivitas yang efektif dalam menekan laju penularan virus. Kegiatan WFH menggunakan fasilitas teknologi IT yang bersifat digitalisasi untuk menopang kegiatan WFH dengan tatap muka jarak jauh sebagai fasilitas serta penyelesaian tugastugas yang dilakukan jarak jauh dari rumah tanpa mengurangi tanggung jawab atas pekerjaan tersebut. Bekerja di rumah sebagai usaha mengurangi interaksi fisik yang biasanya terjadi di ruang kerja atau kantor tanpa mengurangi tanggung jawab dan produktivitas organisasi (Rupietta, 2018). Penelitian ini menguji seberapa besar produktivitas organisasi yang dilakukan melalui WFH. Populasi dalam penelitian ini adalah karyawan warga Jakarta di seputar SCBD (Sudirman Center Business District) sejak Desember 2020 hingga Februari 2021.

\section{Tinjauan Pustaka dan Pengembangan Hipotesis}

\subsection{Pengertian Social Distancing}

Social Distancing atau jarak sosial juga digunakan dalam mitigasi mengurangi dan memutus penyebaran penyakit influenza. Jarak sosial digunakan untuk mengurangi penyebaran penyakit yang dapat terjadi di ruang publik diantaranya sekolah, pusat perbelanjaan, dan ruangan kerja (Rashid, 2020). Bekerja di rumah sebagai usaha mengurangi interaksi fisik yang biasanya terjadi di ruang kerja atau kantor tanpa mengurangi tanggung jawab dan produktivitas organisasi (Rupietta, 2020).

\subsection{Pengertian Work From Home (WFH)}

$\boldsymbol{W F H}$ atau bekerja dari rumah merupakan kebijakan ekonomis jika ditinjau dari aspek operasional karyawan. Kebijakan bekerja di rumah merupakan pilihan ekonomis dan layak untuk mengatasi tantangan dunia global yang semakin modern dan tanpa batas. Kebijakan dirumah juga dapat memberikan dampak pada produktivitas dan profesionalisme karyawan, sehingga kebijakan bekerja di rumah yang diterapkan perusahaan atau organisasi dapat berdampak positif dan negatif (Singh, 2017).

\subsection{Pengertian Aplikasi Video Call}

Persoalan cyber seperti perumpamaan "ruang waktu" bahwa manusia memiliki kehidupan baru diatas dunia nyata. Teori ini lebih menekankan kelompok sosial yang berkembang di dalam dunia maya. Bagaimana terciptanya kelompok- kelompok, bagaimana komunikasi kelompok dan bagaimana sebuah media kelompok di dunia maya mekontruksi pesan penggunanya (Bungin, 2009).

\subsection{Pengertian Produktivitas Kerja}

Produktivitas Organisasi adalah rasio Output dan Input suatu proses produksi dalam periode tertentu (Suafri, 2017).

\subsection{Kerangka Penelitian}

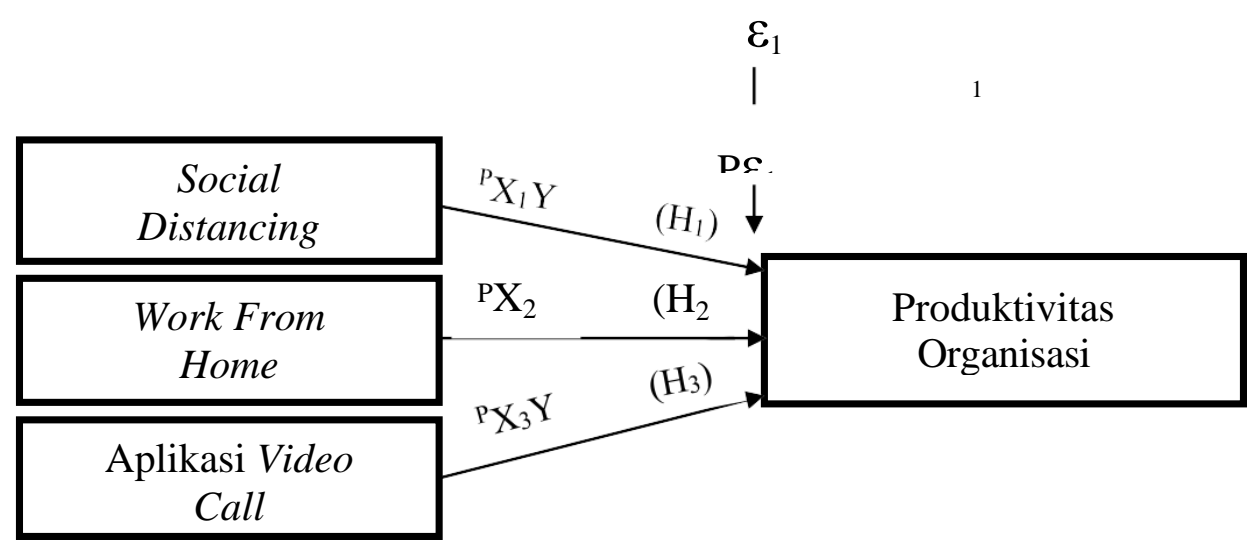

Gambar 1. Kerangka Penelitian

Sumber: Data Primer, 2021. 


\subsection{Hipotesis Penelitian}

Dalam melakukan penelitian, penulis merumuskan hipotesis penelitian karna penelitian ini menggunakan pendekatan kuantitatif. Hipotesis didapat dari diatas adalah sebagai berikut:

$\mathrm{H}_{1}$ : Social Distancing $\left(\mathrm{X}_{1}\right)$ berpengaruh positif dan signifikan terhadap produktivitas organisasi (Y)

$\mathrm{H}_{2}$ : Work From Home $\left(\mathrm{X}_{2}\right)$ berpengaruh positif dan signifikan terhadap produktivitas organisasi (Y)

$\mathrm{H}_{3}$ : Aplikasi video Call $\left(\mathrm{X}_{3}\right)$ berpengaruh positif dan signifikan terhadap produktivitas organisasi (Y)

\section{Metode Penelitian}

Variabel eksogen dependen termasuk di penelitian ini adalah Produktivitas Organisasi (Y) sedangkan variabel independen dalam penelitian ini ada tiga yaitu variabel-variabel endogen: Social Distancing $\left(\mathrm{X}_{1}\right)$, Work From Home $\left(\mathrm{X}_{2}\right)$, Aplikasi Video Call $\left(\mathrm{X}_{3}\right)$. Untuk populasi dalam penelitian ini adalah karyawan di seputar SCBD (Sudirman Central Business District). Penelitian ini menggunakan teknik sampel simple random sampling. Pengumpulan pendapat responden dalam penelitian ini menggunakan kuesioner online google forms, maka mengambil sempel sebanyak 130 karyawan di seputar perkantoran SCBD sebagai data primer. Data yang berhasil terkumpul diolah dengan menggunakan program Microsoft Excel 2010 kemudian di uji menggunakan perangkat lunak program SmartPLS3.0 untuk mengetahui sejauh mana data tersebut layak untuk dipresentasikan dan dianalisis dan apakah hasil analisis data tersebut representasi dari potret sosial yang erjadi di masa pandemi. Uji analisis terdiri dari pengujian validitas, reliabilitas, Hierarchial Component Model (HCM). Setelah itu, data yang fitted dalam uji tersebut selanjutnya dianalisis dalam outer/inner models menggunakan uji kecocokan model (fitted model analysis) diagram jalur penelitian, dan uji hipotesis.

\section{Pembahasan}

\subsection{Uji Validitas dan Reabilitas}

Uji validitas dan Reabilitas seluruh subvariabel pernyataan untuk variabel yang dianalisi rerata terindikasi nilai $>0,5$, sehingga kesimpulannya setiap pernyataan untuk seluruh variabel adalah valid. Serta pada uji reabilitas dapat dilihat nilai Cronbach's Alpha dari masing-masing variabel memiliki nilai rerata $>0,7$, maka indikator pernyataan dari masing-masing variabel dapat dinyatakan reliabel dan dapat digunakan.

Tabel 1. Nilai Average Variance Extacted (AVE)

\begin{tabular}{|c|c|}
\hline Variabel/Konstruk & $\begin{array}{c}\text { Average Variance Extracted (AVE) } \\
(>\mathbf{0 , 5})\end{array}$ \\
\hline Social Distancing $\left(\mathrm{X}_{1}\right)$ & 0,595 \\
\hline Work From Home $\left(\mathrm{X}_{2}\right)$ & 0,651 \\
\hline Aplikasi Video Call $\left(\mathrm{X}_{3}\right)$ & 0,544 \\
\hline Produktivitas Organisasi $(\mathrm{Y})$ & 0,523 \\
\hline
\end{tabular}

Sumber: Output SmartPLS 3.0, 2021

Pada Tabel 1 dapat dilihat nilai AVE dari setiap variabel diatas 0,5 sehingga dapat dikatakan valid secara diskriminasi berdasarkan AVE. 
Tabel 2. Hasil Pegujian Reliabilitas Masing-masing Variabel

\begin{tabular}{|c|c|c|c|}
\hline \multirow{2}{*}{ Variabel/Konstruk } & \multicolumn{2}{|c|}{ Hasil Pengujian } & \multirow{2}{*}{$\begin{array}{c}\text { Keterangan } \\
\text { Reliabilitas }\end{array}$} \\
\cline { 2 - 3 } & $\begin{array}{c}\text { Cronchbach's } \\
\text { Alpha }()\end{array}$ & Composite Reliability () & Reliabel \\
\hline Social Distancing $\left(\mathrm{X}_{1}\right)$ & 0,861 & 0,897 & Reliabel \\
\hline Work From Home $\left(\mathrm{X}_{2}\right)$ & 0,889 & 0,917 & Reliabel \\
\hline Aplikasi Video Call $\left(\mathrm{X}_{3}\right)$ & 0,830 & 0,876 & Reliabel \\
\hline Produktivitas Organisasi $(\mathrm{Y})$ & 0,845 & 0,883 & \\
\hline
\end{tabular}

Sumber: Output SmartPLS 3.0, 2021

Berdasarkan pada Tabel 2. terlihat bahwa nilai cronbach's alpha masing-masing variabel memiliki nilai lebih dari 0,7 dan composite reliability dari masing-masing variabel memiliki nilai lebih $>0,5$ sehingga dapat disimpulkan bahwa seluruh kosntruk dalam penelitian ini reliabel.

\subsection{Uji Hierarchical Component Model (HCM)}

Tabel 3. Hierarchical Component Model

\begin{tabular}{|c|c|c|c|}
\hline Variabel & Indikator & $\begin{array}{c}\text { Path } \\
\text { Coefficien } \\
\text { ts }\end{array}$ & R Square \\
\hline \multirow[t]{2}{*}{ Social Distancing $\left(\mathrm{X}_{1}\right)$} & 1. Individu & \multirow{2}{*}{0,052} & \multirow{10}{*}{0,986} \\
\hline & 2. Lingkungan & & \\
\hline \multirow[t]{3}{*}{ Work From Home $\left(\mathrm{X}_{2}\right)$} & 1. Individu & \multirow{3}{*}{0,047} & \\
\hline & 2. Lingkungan & & \\
\hline & 3. Fasilitas & & \\
\hline \multirow[t]{5}{*}{ Aplikasi Video Call $\left(\mathrm{X}_{3}\right)$} & 1. Perangkat & \multirow{5}{*}{0,924} & \\
\hline & 2. Kualitas koneksi & & \\
\hline & 3. Jumlah Peserta & & \\
\hline & 4. Efektifitas & & \\
\hline & 5. Fleksibilitas & & \\
\hline
\end{tabular}

Sumber: Output SmartPLS 3.0, 2021

$\mathrm{R}$ Square sebagai penentu atau determinasi pada tabel hierarchical component model guna mengindikasikan besaran kontribusi masing-masing variabel eksogen terhadap variabel endogen berdasarkan tabel 3 nilai R Square 0,986 atau 98,6\% Produktivitas Organisasi dipengaruhi oleh Social Distancing, Work From Home, Aplikasi Video Call sedangkan sisanya sebesar 1,4\% dipengaruhi oleh faktor-faktor lain yang tidak termasuk dalam peneliti. 


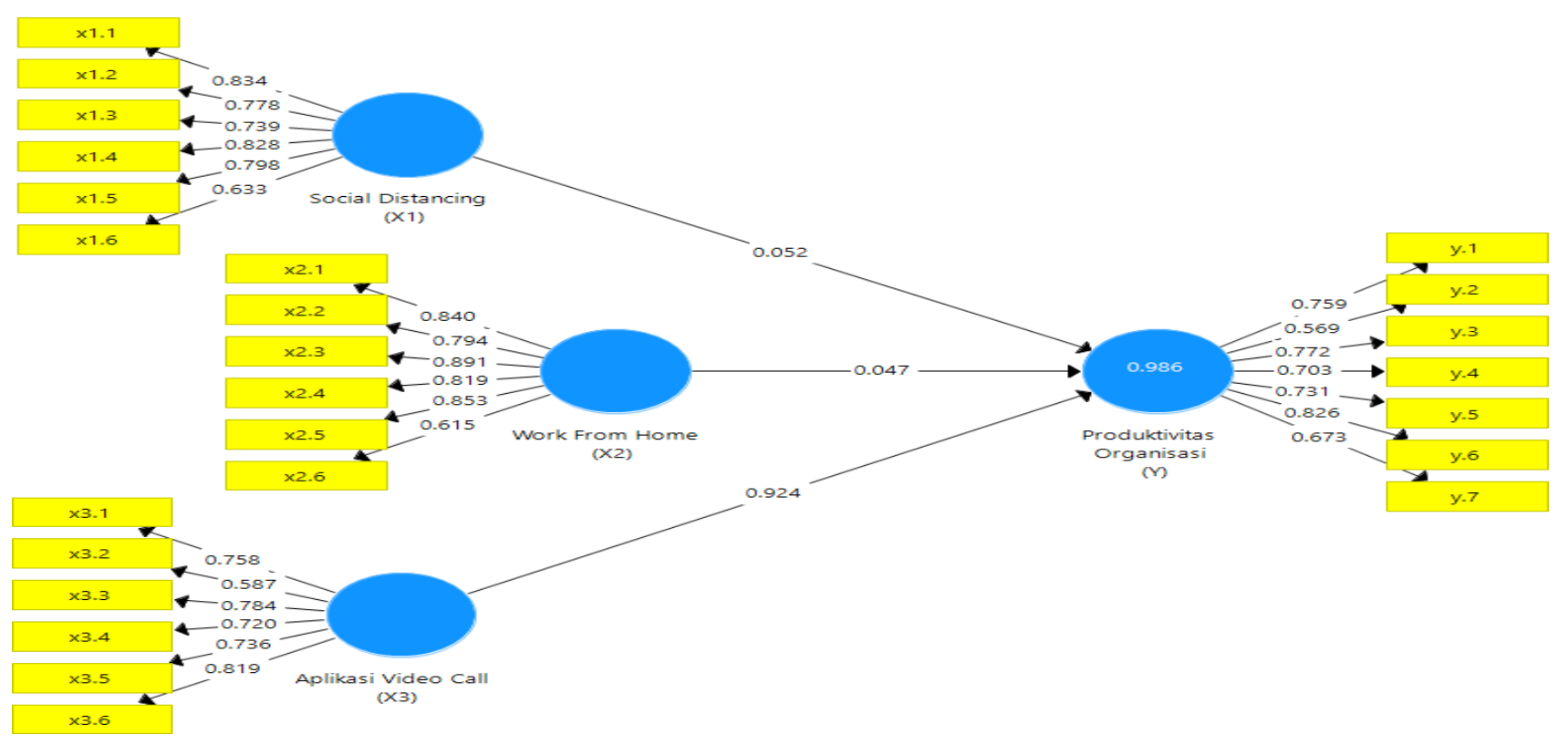

Gambar 2. Tampilan Output PLS Algorithme: Diagram Jalur Penelitian

Sumber: Output SmartPLS 3.0, 2021

\subsection{Uji Kecocokan Model (Uji Fit)}

Tabel 4. Hasil Uji Kecocokan Model

\begin{tabular}{|l|l|c|c|}
\hline $\begin{array}{l}\text { Model } \\
\text { Pengukuran }\end{array}$ & Kriteria & $\begin{array}{c}\text { Hasil } \\
\text { Pengujian }\end{array}$ & Keterangan \\
\hline SRMR & $<0.08$ (Henseler et. al, 2014) & 0,051 & Model Fit \\
\hline NFI & $>0.90$ (Lohmöller, 1989) & 0,931 & Model Fit \\
\hline RMS Theta & $<0.12$ (Lohmöller, 1989) & 0,105 & Model Fit \\
\hline
\end{tabular}

Sumber: Output SmartPLS 3.0, 2021

Mengacu pada sejumlah pengujian pada Tabel 4., diketahui nilai SRMR, NFI dan RMS Theta secara kseluruhan masuk pada kriteria yang ditetapkan, sehingga dapat dipastikan bahwa terjadi konsistensi dan kecocokan dengan model menurut Goodness of Fit.

\subsection{Uji Hipotesis}

Tabel 5. Hasil Uji Signifikansi dari Indikator ke Variabel

\begin{tabular}{|l|l|l|l|l|}
\hline $\begin{array}{l}\text { Variabel/ } \\
\text { Konstruk }\end{array}$ & Indikator & $\begin{array}{l}\text { T- } \\
\text { Statistic }\end{array}$ & $\begin{array}{l}\text { P- } \\
\text { Values }\end{array}$ & $\begin{array}{l}\text { Keterangan } \\
\text { Signifikansi }\end{array}$ \\
\hline & X1.1 Individu & 31.790 & 0,000 & Signifikan \\
\cline { 2 - 5 } & X1.2 Individu & 17.356 & 0,000 & Signifikan \\
\hline
\end{tabular}




\begin{tabular}{|c|c|c|c|c|}
\hline \multirow{4}{*}{$\begin{array}{l}\text { Social } \\
\text { Distancing } \\
(X 1)\end{array}$} & $\begin{array}{l}\text { X1.3 Lingkungan } \\
\text { Kerja }\end{array}$ & 14.005 & 0,000 & Signifikan \\
\hline & $\begin{array}{l}\text { X1.4 Lingkungan } \\
\text { Kerja }\end{array}$ & 25.336 & 0,000 & Signifikan \\
\hline & $\begin{array}{l}\text { X1.5 Lingkungan } \\
\text { Kerja }\end{array}$ & 18.362 & 0.000 & Signifikan \\
\hline & $\begin{array}{l}\text { X1.6 Lingkungan } \\
\text { Kerja }\end{array}$ & 7.132 & 0,000 & Signifikan \\
\hline \multirow{6}{*}{$\begin{array}{l}\text { Work } \\
\text { From } \\
\text { Home (X2) }\end{array}$} & X2.1 individu & 18.601 & 0,000 & Signifikan \\
\hline & X2.2 individu & 14.903 & 0,000 & Signifikan \\
\hline & $\begin{array}{l}\text { X2.3 Lingkungan } \\
\text { Kerja }\end{array}$ & 41.237 & 0,000 & Signifikan \\
\hline & $\begin{array}{l}\text { X2.4 Lingkungan } \\
\text { Kerja }\end{array}$ & 21.052 & 0,000 & Signifikan \\
\hline & $\begin{array}{l}\text { X2.5 Lingkungan } \\
\text { Kerja }\end{array}$ & 26.380 & 0,000 & Signifikan \\
\hline & $\mathrm{X} 2.6 \quad$ Fasilitas & 6,759 & 0,000 & Signifikan \\
\hline \multirow{6}{*}{$\begin{array}{l}\text { Aplikasi } \\
\text { Video Call } \\
\text { (X3) }\end{array}$} & X3.1 Perangkat & 13.098 & 0,000 & Signifikan \\
\hline & X3.2 Perangkat & 7.096 & 0,000 & Signifikan \\
\hline & $\begin{array}{l}\text { X3.3 Kualitas } \\
\text { Koneksi }\end{array}$ & 21.439 & 0,000 & Signifikan \\
\hline & $\begin{array}{l}\text { X3.4 Jumlah } \\
\text { Peserta }\end{array}$ & 12.040 & 0,000 & Signifikan \\
\hline & $\begin{array}{l}\text { X3.5 Jumlah } \\
\text { Peserta }\end{array}$ & 13.350 & 0,000 & Signifikan \\
\hline & X3.6 Perangkat & 40.004 & 0,000 & Signifikan \\
\hline \multirow{5}{*}{$\begin{array}{l}\text { Produktivi } \\
\text { tas } \\
\text { Organisasi } \\
\text { (Y) }\end{array}$} & $\begin{array}{l}\text { Y.1 Ketepatan } \\
\text { Waktu }\end{array}$ & 13.190 & 0,000 & Signifikan \\
\hline & Y.2 Hasil Kerja & 6.685 & 0,000 & Signifikan \\
\hline & $\begin{array}{l}\text { Y.3 Kemampuan } \\
\text { Berkomunikasi }\end{array}$ & 18.477 & 0,000 & Signifikan \\
\hline & $\begin{array}{l}\text { Y.4 Membagi } \\
\text { Waktu }\end{array}$ & 10.504 & 0,000 & Signifikan \\
\hline & Y.5 Data dan & 13.886 & 0,000 & Signifikan \\
\hline
\end{tabular}




\begin{tabular}{|l|l|l|l|l|}
\hline pulang tepat waktu & & & \\
\cline { 2 - 5 } & Y.6 Waktu Lembur & 39.852 & 0,000 & Signifikan \\
\cline { 2 - 5 } & Y.7 Kebijakan & 7.444 & 0,000 & Signifikan \\
\hline
\end{tabular}

Sumber: Output SmartPLS 3.0, 2021

\subsection{Variabel Social Distancing $\left(X_{I}\right)$}

H0: $\rho Y X 1<0$ Social Distancing tidak berpengaruh positif dan signifikan terhadap Produktivitas Organisasi. H1: $\rho Y X 1>0$ Social Distancing berpengaruh positf dan signifikan terhadap Produktivitas Organisasi. Berdasarkan hasil pengolahan data diperoleh nilai koefisien jalur sebesar 0,052 dan pvalue sebesar 0,020 (signifikan), artinya Social Distancing berpengaruh signifikan dengan arah positif dan terhadap Produktivitas Organisasi.

\subsection{Variabel Work From Home $\left(\mathrm{X}_{2}\right)$}

H0: $\rho Y X 2<0$ Work From Home tidak berpengaruh positif dan signifikan terhadap Produktivitas Organisasi. H2: $\rho Y X 2>0$ Work From Home berpengaruh positf dan signifikan terhadap Produktivitas Organisasi. Berdasarkan hasil pengolahan data diperoleh nilai koefisien jalur sebesar 0,047 dan pvalue sebesar 0,034 (signifikan), artinya Work From Home berpengaruh signifikan dengan arah positif dan terhadap Produktivitas Organisasi.

\subsection{Variabel Aplikasi Video Call $\left(X_{3}\right)$}

H0: $\rho$ YX3 < 0 Aplikasi Video Call tidak berpengaruh positf dan signifikan terhadap Produktivitas Organisasi. H3: $\rho Y X 3>0$ Aplikasi Video Call berpengaruh positf dan signifikan terhadap Produktivitas Organisasi. Berdasarkan hasil pengolahan data diperoleh nilai koefisien jalur sebesar 0,924 dan p-value sebesar 0,001 (signifikan), artinya Aplikasi Video Call berpengaruh signifikan dengan arah positif terhadap Produktivitas Organisasi.

\section{Kesimpulan}

Mengacu pada pokok bahasan dalam penelitian ini, hasil uji analisis data berdasarkan pengujianpengujian hipotesis dapat disampaikan kesimpulan: Variabel Social Distancing mempunyai pengaruh positif dan signifikan terhadap Produktivitas Organisasi pada karyawan di seputar perkantoran SCBD di Jakarta. Variabel Work From Home mempunyai pengaruh positif dan signifikan terhadap produktivitas Organisasi pada karyawan pada karyawan di seputar perkantoran SCBD di Jakarta. Variabel aplikasi Video Call mempunyai pengaruh positif dan signifikan terhadap Produktivitas Organisasi pada karyawan pada karyawan di seputar perkantoran SCBD di Jakarta.

\section{Implikasi Manajerial}

Penelitian ini memberikan beberapa implikasi manajerial untuk pada karyawan di seputar perkantoran SCBD di Jakarta, agar dapat terus meningkatkan Produktivitas Organisasi d masa pandemi dan menurunkan tingkat penyebaran virus di Provinsi DKI Jakarta. Dapat diketahui bahwa selama Kebijakan Social Distancing karyawan dapat menekan laju pandemi, dpata meningkatkan Produktivitas Organisasi, karena banyaknya kasus jumlah pasien yang meninggal, bukan saja menutunkan produktivitas organisasi tetapinakan terjadi fatalisme tinggi yaitu membutuhkan karyawan baru dan aspekmsosial lainnya yang sekaligus berdampak pada produktivitas organisasinsecara keseluruhan. Para karyawan yang bekerja dari rumah juga harus tetap menjaga menjaga jarak 2 meter serta meningkatkan kinerjanya. Pada daat perusahaan mengekuarkan kebijakan Work From Home proses aktivitas kerja harus tetap berjalan dengan seksama, dalam kondisi pandemi ini kordinasi seerta pengaturan kerja harus tetap berjalam secara terstruktur dan terencana. Pemanfaatan digital platform yang menggunakan software Aplikasi Video Call, Menggunakan Aplikasi Video Call dapat digunakannsebagai forum diskusi, forum pelaporan, forum kordinasi antar karyawan dan para pemegang kepentingan di dalam organisasi masing-masing dalam memenuhi kebutuhan untuk tetap produktif dan mencapau sasaran organisasi secara keseluruhan. 


\section{Saran}

1. Untuk penerapan kebijakan Social Distancing pada seluruh karyawan di Provinsi DKI Jakarta dalam masa wabah pandemi Covid-19 seperti ini sangat sesuai dengan kebijakan pemerintah pusat yang diatur oleh Perpres dan Permen disertai regulasi yang jelas seperti memberikan punishment bagi pelanggar kebijakan untuk meningkatkan proteksi warga masyarakat terhadap virus, tetapi tetap menjaga produktivitas organisasi.

2. Untuk melaksanakan kebijakan Work From Home pada para karyawan di Provinsi DKI Jakarta sebaiknya menyediakan fasilitas kuota internet secara cuma-cuma, sehingga dapat meringankan biaya bagi karyawan dan sekaligus berdampak pada produktivitas serta kinerja karyawan.

3. Aplikasi Video Call dalam pelaksanaanya para karyawan di Provinsi DKI Jakarta diperlukan pemilihan aplikasi yang sesuai dan juga harus disertai fasilitas dari dinas, karena diyakini dapat meningkatkan produktivitas organisasi.

\section{Referensi}

Badan Pusat Statistik. (2021). Perkembangan Terakhir Statistik Penyebaran Virus COVID 19 di Indonesia.

Eko, Widodo Suparno. (2015). Manajemen Pengembangan Sumber Daya Manusia. Yogyakarta: Pustaka Pelajar.

Faeni, Dewi Puspaningtyas. Wahyudi, Widi. Kuncoro, Aris Wahyu. (2017). Manajemen Sumber Daya Manusia Dasar. Jakarta: Layout MSDM Dasar.

Hadi, Sutrisno. (2004). Penelitian Riset. Yogyakarta: BPFE.

Hair, Joseph F., et al. (2010). Multivariate Data Analysis. Upper Saddle River, NJ Prentice Hall.

Kerlinger. (1993). Korelasi dan Analisis Regresi Gsaya. Yogyakarta: Nur Cahaya.

Narimawati, Umi. (2008). Metodologi Penelitian Kualitatif dan Kuantitatif, Teori dan Aplikasi. Bandung: Agung Media.

Sugiyono. (2014). Metode Penelitian Kuantitatif, Kualitatif dan R\&D. Bandung: Alfabeta.

Handayani, Wahyu Ningrum. Hati, Shinta. Pengaruh Lingkungan Kerja Fisik Terhadap Produktivitas Organisasi Karyawan Operator Bagian Produksipada Perusahaan Manufaktur Di PT. ABC Batam. Jurnal Aplikasi Administrasi, Vol 21, No 1.

Marwansyah. (2016). Manajemen Sumber Daya Manusia. Edisi Dua. Cetakan keempat. Bandung: Alfabeta, CV.

Kidwell, I Jane. Booth, Alan. (1977). Social Distance and Intergenerational Relations. Journal The Gerontologist, Vol 17 No 5.

Rashid H. Ridda I. King C. Dkk. (2020). Social distancing. National Centre for Immunisation Research and Surveillance and $\uparrow$ School of Public Health \& Community Medicine, University of New South Wales. Journal Evidence Summary.

Singh, Ravin. Kumar, Madyam Akhsay. Varghese, Samuel T. (2017). Impact of Working Remotely On Productivity and Professionalism. IOSR Journal of Business and Management. Vol 19. No 5.

Sumajow, Elisa. Tewal, Benhard. Lumintang Genita. (2018). Pengaruh Karakteristik Pekerjaan, Lingkungan Kerja Dan Disiplin Kerja Terhadap Produktivitas Organisasi Pegawai Pada Dinas Pendidikan Daerah Provinsi Sulawesi Utara. Jurnal EMBA, Vol 6 No 4. 